\title{
OUT-OF-PLANE PERFORMANCE OF A PARTIALLY FILLED REINFORCED CONCRETE MASONRY WALL WITH RIBRAFT'M FLOOR
}

\author{
S.S. Singh ${ }^{1}$, N. Cooke ${ }^{2}$ and D.K. Bull ${ }^{3}$
}

\begin{abstract}
This paper presents the results of an experimental investigation by Singh (1998) [1], into the serviceability and strength performance of a full-scale reinforced concrete masonry wall with Ribraft ${ }^{\mathrm{TM}}$ floor. The wall was C-shaped in plan and was partially grouted. The results show that the masonry wall behaved in a ductile manner, and that response remained elastic to an out-of-plane load of approximately $6 \mathrm{kPa}$. The wall reached the Ultimate Limit State deflection criterion of $50 \mathrm{~mm}(2 \% \mathrm{drift})$ at a load of $7.6 \mathrm{kPa}$. The crack and deflection patterns were as predicted by the yield-line theory, which however, provided a conservative estimate of the out-of-plane failure load of $5.0 \mathrm{kPa}$. The test was halted at a load of $10.7 \mathrm{kPa}$ at which point the main wall had not collapsed and was still being supported by the return walls. The Ribraft ${ }^{\mathrm{TM}}$ floor behaved elastically, except for a local failure restricted to minor spalling of the wall foundations.
\end{abstract}

\section{INTRODUCTION}

This paper presents the results of an experimental investigation by Singh (1998) [1] into the out-of-plane strength and level of ductile performance of a partially grouted reinforced concrete masonry wall founded on a Ribraft ${ }^{\mathrm{TM}}$ floor.

Available published literature on such experimental work has been limited to the testing of scaled models and panels with artificially imposed boundary conditions. The out-of-plane static response of slender masonry walls was studied by the SEAOSC-ACI committee (Adham et al (1990) [2]). The aim of the programme was to check the empirical limitation of height to thickness ratio imposed by masonry codes and concluded that there was no need to impose such limits and that masonry walls can sustain loads greater than those needed to cause cracking. Abboud et al (1990) [3] tested scale model reinforced block walls under monotonic and cyclic loads with defined boundary conditions. It was confirmed that walls with normal steel ratios exhibit large inelastic deformations and that cyclic loading significantly reduced ductility. Sveinsson et al (1988) [4] reported that large inelastic deflections were sustained during dynamic out-of-plane tests on reinforced masonry walls, and that no spalling of the face shell or other apparent damage occurred during the tests, other than at the base joint. Hamid (1990) [5] tested grouted and ungrouted walls and concluded that the walls exhibited ductile behaviour with pinched hysteresis loops, although the pinching was eliminated by using staggered reinforcement.

\footnotetext{
${ }^{1}$ Engineer, Shri Singh and Associates, Suva, Fiji, (Member)

2 Senior Lecturer, Dept. of Civil Engineering,

University of Canterbury, Christchurch, (Member)

${ }^{3}$ Director, Technical Services, Holmes Consulting

Group, Christchurch, (Member)
}

The TCCMAR programme of co-ordinated research into masonry, in the USA and Japan, started in 1985. Since that time, seven projects have dealt with the in-plane and out-ofplane loading of masonry walls. Work by Abboud (1996) [6], as part of the TCCMAR programme, showed that under monotonic loads, the percentage and location of vertical steel have an effect on wall load-deflection curves, strength and ductility. A five-storey building was tested, in-plane by Priestley (1994) [7] as part of the TCCMAR programme. Although out-of-plane motions were observed, the study concluded that stability was not a problem, and the design criteria is somewhat conservative.

Available analytical techniques included the use of elastic plate bending theory, the empirical "strip method", British moment coefficients, finite element method and conventional yield line theory (Park and Gamble, 1980) [8]. Essawy and Drysdale (1988) [9] found that yield line theory was the most appropriate analytical approach and that it could be applied as a simple and "reasonably accurate" way of predicting the strength capacity of masonry walls. Seah and Dawe (1993) [10] found yield line theory particularly useful in determining the out-of-plane ultimate strength of masonry members with unusual boundary conditions.

Reinforced masonry walls exhibit considerable inelastic behaviour (Sveinsson et al, 1988 [4]), and wall deflections are a critical measure of their performance, especially where deformation compatibility is required for attached members. A study by Abboud et al (1993) [11] showed that methods developed to estimate deflections, based on curve fitting of 
test data and on the bilinear model of deflection, were inadequate.

This paper describes the investigation into the behaviour of a $9.4 \mathrm{~m}$ long, $2.4 \mathrm{~m}$ high, partially grouted, "C" shaped reinforced masonry wall with two $2.5 \mathrm{~m}$ long return walls. The walls were founded on a reinforced concrete waffle slab or Ribraft ${ }^{\mathrm{TM}}$ floor. The test wall was full-scale and was tested outside in an open site rather than in laboratory conditions.

The primary aim of the project was to provide experimental data which would aid in the revision of the "Code of Practice for Masonry Structures Not Requiring Specific Design", NZS4229:1986 [12]. The wall deviated in many ways from the current requirements of this code. These included a different bond-beam corner joint detail, less horizontal reinforcement, and a bond-beam detail currently only used for walls supported by a roof diaphragm, which was not included in the test. The wall was $2.2 \mathrm{~m}$ longer than that currently permitted, and was founded on a Ribraft ${ }^{\mathrm{TM}}$ floor instead of a standard reinforced masonry or concrete foundation. The bond-beam corner detail, as illustrated in Figure 1, contained additional reinforcement to provide an internal couple in order to increase shear resistance and the integrity of the corner regions under loading.
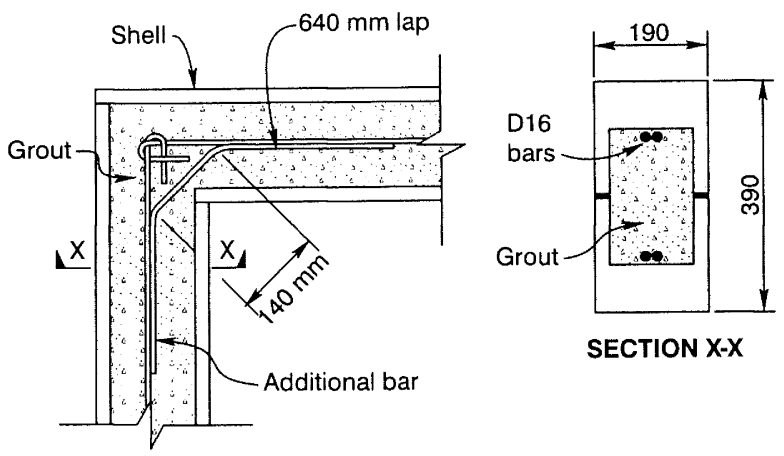

Figure 1: Corner reinforcement details for bond beam.

The experimental programme was used to evaluate the performance of the wall and floor under code level Serviceability Limit State and Ultimate Limit State loads, as calculated using NZS4203:1992 [13]. The influence of the bond-beam type, corner joint details, wall length, foundation type and return walls were evaluated. This information could be used in refining methods of predicting the response of such walls, as well as decrease some of the conservatism in design practice associated with reinforced concrete masonry.

\section{TEST WALL \& FLOOR}

The reinforced concrete masonry wall was " $\mathrm{C}$ " shaped in plan, $9.4 \mathrm{~m}$ long, $2.4 \mathrm{~m}$ high, with $2.5 \mathrm{~m}$ long return walls at each end: " 20 " Series blocks were used in construction, being the most commonly used block in New Zealand, with D12 bars placed vertically at $800 \mathrm{~mm}$ centres, which is the minimum amount of steel required by NZS4229:1986 [12].
A $400 \mathrm{~mm}$ high $\times 190 \mathrm{~mm}$ wide bond-beam was located in the top two courses of the wall, with 1-D16 bar placed horizontally in each course and held together by R6 ties at $800 \mathrm{~mm}$ centres. Only cavities containing reinforcement were grouted. The wall contained no openings (windows or doors.) These details are illustrated in Figure 2. The vertically reinforced cells and the horizontal bond beam at the top of the wall were grout filled in one continuous operation. The grout contained an expansive admixture to compensate for grout shrinkage. A pencil vibrator was used to ensure that adequate consolidation had occurred. Inspection ports were made at the base of the wall, as is required by NZS4229:1986 [12].

The foundation beam for the wall was part of the Ribraft ${ }^{\mathrm{TM}}$ floor system designed by Firth Industries. It was $305 \mathrm{~mm}$ deep x $300 \mathrm{~mm}$ wide and was joined to reinforced concrete cross beams at $1200 \mathrm{~mm}$ centres. The Ribraft ${ }^{\mathrm{TM}}$ waffle floor slab was $9400 \mathrm{~mm}$ long x $3600 \mathrm{~mm}$ wide and $305 \mathrm{~mm}$ deep. It comprised of a $300 \mathrm{~mm}$ wide $\times 305 \mathrm{~mm}$ deep ring beam, as shown in Figure 3, containing 3-HD12 longitudinal bars. An $85 \mathrm{~mm}$ topping slab, containing one layer of cold drawn wire mesh at mid-depth, was supported by $100 \mathrm{~mm}$ wide ribs at $1200 \mathrm{~mm}$ centres in each direction. Blocks of polystyrene formers were used to form the ribs, each of which contained a single HD12 bar. The only change made in reinforcing details from that in standard Ribraft ${ }^{\mathrm{TM}}$ floors, is that all reinforcement in the ribs contained hooks at each end to increase bar development and anchorage.

The longitudinal reinforcement in the foundation beam consisted of $3 \mathrm{HD} 12$ bars, one more than the 2D12 bars required by NZS4229: 1986 [12]. However, because the foundation beam is $300 \mathrm{~mm}$ wide, the code requires four bars in the foundation whereas only three have been provided in this test wall. This lack of compliance did not pose any problems during the test.

\section{MATERIALS}

Design and construction of the wall was as for Grade B masonry in NZS4229: 1986 [12]. The wall was constructed using commercially available labour and materials. The materials met the minimum criteria as set out in NZS4229: 1986 [12]

The Ribraft ${ }^{\mathrm{TM}}$ floor was constructed using Grade 430 reinforcing steel, and specified compression strength $\mathrm{f}_{\mathrm{c}}=20$ MPa pump-mix concrete specially designed for raft foundations. The topping slab contained one layer of 150 $\mathrm{mm} \times 150 \mathrm{~mm}$ cold drawn wire mesh of $7.12 \mathrm{~mm}$ diameter, with a lower characteristic strength of $\mathrm{f}_{\mathrm{y}}=485 \mathrm{MPa}$.

The results of all material tests are summarised in Tables 1,2 and 3.

From the tabulated results above, the lower bound design compressive strength of the concrete masonry during wall testing was calculated, using formulae from Appendix C, NZS4230:1990 [14].

$$
f_{m}^{\prime}=0.45 \alpha f_{c b}^{\prime}+0.675(1-\alpha) f_{g}^{\prime}
$$


$\therefore f_{m}^{\prime}=0.45 * 0.40 * 25.2+0.675(1-0.4) * 25.3$

$\therefore f_{m}^{\prime}=14.8 \mathrm{MPa}$

where $\hat{f}_{c b}$ is the average compression strength of the masonry units,

$\mathrm{f}_{\mathrm{g}}$ is the average grout strength, $f_{m}$ is the masonry design compression strength and $\alpha$ is the ratio of net area to gross area of the masonry units.

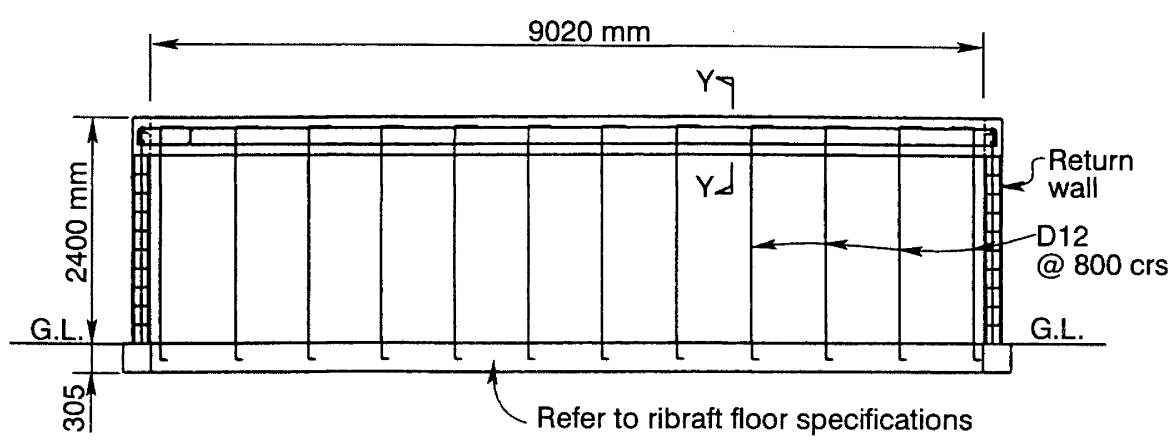

WALL ELEVATION 1

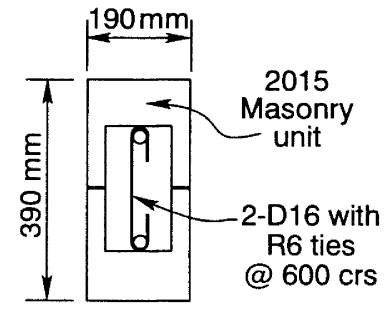

SECTION Y-Y
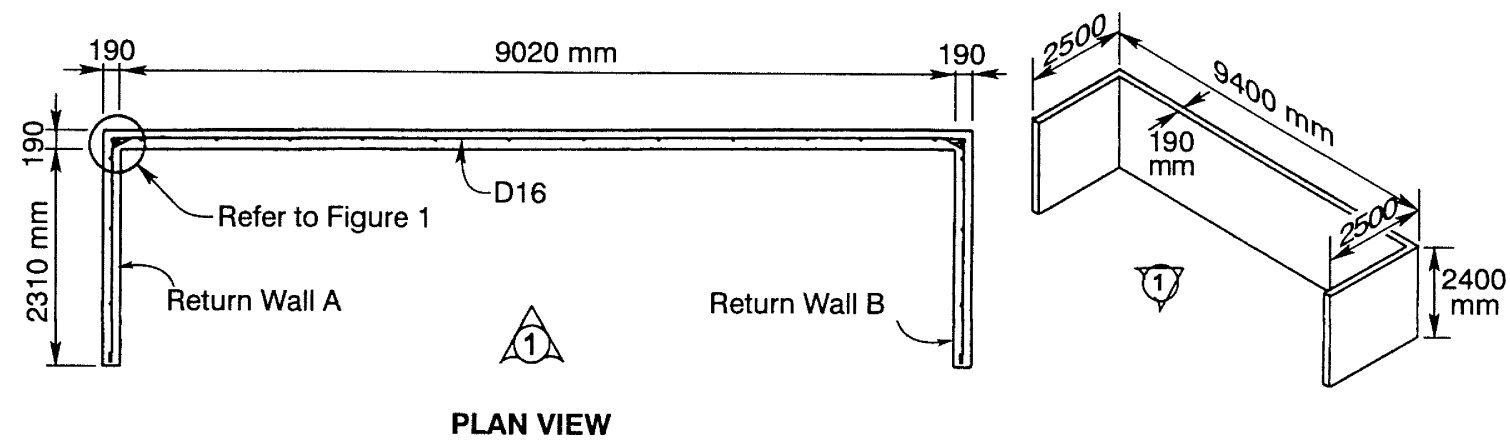

Figure 2: Concrete masonry wall layout and reinforcement details.

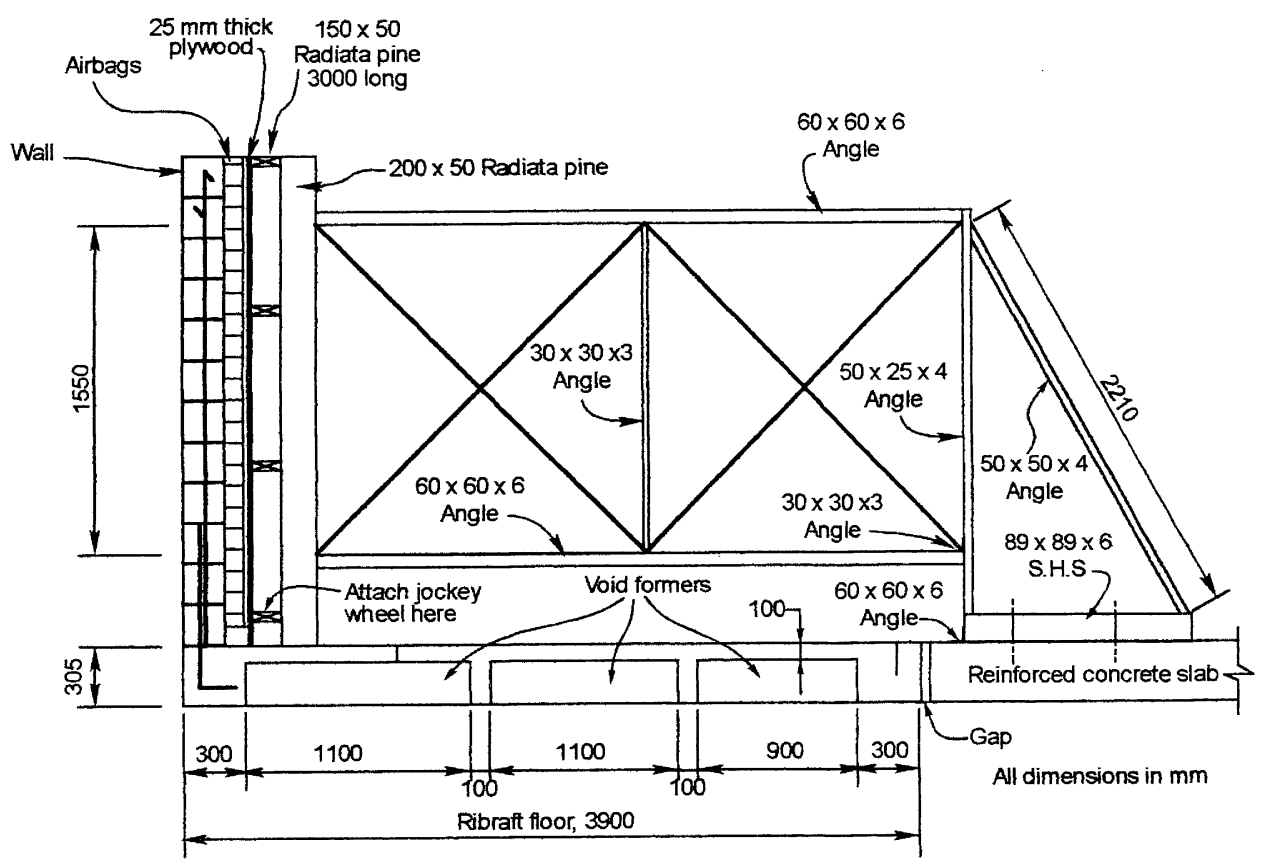

Figure 3: Loading frame and floor details. 
Table 1: Reinforcing Steel Test Results.

\begin{tabular}{|c|c|c|c|c|}
\hline $\begin{array}{c}\text { Bar Diameter } \\
(\mathbf{m m})\end{array}$ & $\begin{array}{c}\mathbf{f}_{\mathbf{y}} \\
(\mathbf{M P a})\end{array}$ & $\begin{array}{c}\mathbf{f}_{\mathbf{u}} \\
(\mathbf{M P a})\end{array}$ & $\begin{array}{c}\text { Elongation } \\
(\mathbf{\%})\end{array}$ & Description \\
\hline 12 & 464 & 603 & 16.5 & $\begin{array}{c}\text { Ribraft } \\
\text { Reinforcement }\end{array}$ \\
\hline 12 & 332 & 459 & 26.5 & $\begin{array}{c}\text { Wall Vertical } \\
\text { Reinforcement }\end{array}$ \\
\hline 16 & 325 & 463 & 26.0 & $\begin{array}{c}\text { Wall Bond-Beam } \\
\text { Reinforcement }\end{array}$ \\
\hline
\end{tabular}

Note: $f_{y}$ and $f_{u}$ are the lower characteristic yield strength and ultimate tensile strength of the steel respectively; Elongation: total elongation.

Table 2: Concrete Masonry Block Test Results.

\begin{tabular}{||c|c|c|c|c||}
\hline \hline \multicolumn{3}{|c|}{ Test Data } & Comments & Description \\
\hline $\begin{array}{c}\text { Block } \\
\text { Type }\end{array}$ & Age (days) & $\mathbf{f}_{\mathbf{p}}{ }_{\mathbf{p}}(\mathbf{M P a})$ & Tested to NZS 3102 & Tested during wall test \\
\hline 2005 & 140 & 24.3 & $\begin{array}{c}\text { Open Ended Masonry } \\
\text { Units }\end{array}$ \\
\hline 2015 & 208 & 26.2 & Tested during wall test & $\begin{array}{c}\text { Knock-in Bond-Beam } \\
\text { Masonry Units }\end{array}$ \\
\hline
\end{tabular}

Note: $f_{p}^{\prime}$ is the compressive strength of stacked masonry units bedded on mortar.

Table 3: Concrete Cylinder (100 mm dia. x $200 \mathrm{~mm}$ high) Test Results.

\begin{tabular}{||c|c|c|}
\hline Description & Age (days) & $\begin{array}{c}\text { Compressive Strength } \\
(\mathbf{M P a})\end{array}$ \\
\hline Bond-Beam Mortar & 94 & 21.0 \\
\hline Wall Mortar & 94 & 8.0 \\
\hline Grout & 92 & 25.3 \\
\hline Ribraft $^{\mathrm{TM}}$ Floor Concrete & 100 & 21.5 \\
\hline
\end{tabular}

Note: Test cylinders were wrapped in DPC and stored in the shade, near the test wall.

The original derivation of Eq. 1 contains a multiplying factor of 0.75 to give a conservative lower bound value to the test results from which they were derived. If this factor is neglected then the masonry strength $\mathrm{f}_{\mathrm{m}}$ is $19.7 \mathrm{MPa}$. All material strengths used in the formulation above were obtained from tests conducted at a time when the wall was being loaded to failure. At this stage, the masonry units were between 140 to 208 days of age, and the grout in the wall was 92 days old.

\section{INSTRUMENTATION}

Reinforced paper airbags were used to apply a uniform pressure to the main $9 \mathrm{~m}$ wall. The airbags, when inflated to $300 \mathrm{~mm}$ thick, occupy an area of $600 \mathrm{~mm} \times 1150 \mathrm{~mm}$. The airbags were overlapped to accommodate this amount of inflation and were mounted on a plywood and timber strongback attached to three steel frames, as detailed in Figure 3. The frames were anchored into reaction slabs behind and separate from the Ribraft ${ }^{\mathrm{TM}}$ floor, so that reaction forces induced by loading were not transferred into the Ribraft ${ }^{\mathrm{TM}}$ floor.

Twenty-four linear potentiometers were used to monitor deflections of the wall. These were of variable ranges and sensitivity, with maximum travel ranging from $50 \mathrm{~mm}$ to 500 $\mathrm{mm}$. Twenty-seven dial gauges were also used during the testing program; details are given in Figure 4. The linear potentiometers were used to measure the horizontal displacement profile of the bond beam and the vertical profile of the main wall at three locations.

A Demec gauge and extension bar were used to measure inplane strains along the top faces of the main and return wall bond-beams so that the out-of-plane curvature of the bondbeam could be calculated. The curvatures were used for checking out-of-plane deflections as measured by the potentiometers. The dial gauges were used to monitor displacements in the direction of the load to check the sliding 
of the floor. Four pairs were used to monitor rotations at the base of the wall and $600 \mathrm{~mm}$ above. Others were used to measure the vertical separation between the foundation and the base of the wall.

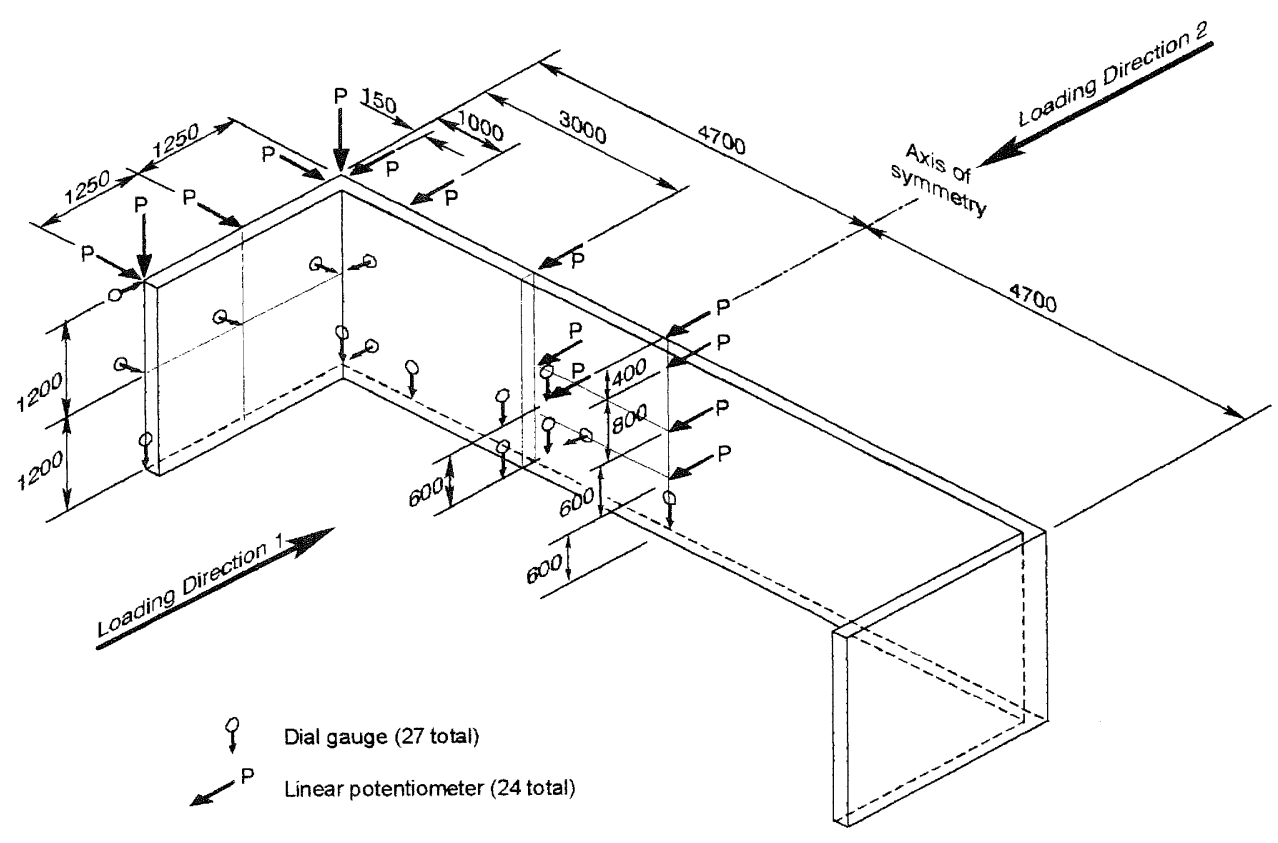

Figure 4: Potentiometers and dial gauges locations, load directions.

Ninety-six electrical resistance foil strain gauges were installed on the reinforcing steel in the wall-floor assembly. Twenty strain gauges were placed on the reinforcement in the floor and the remainder were placed in regions of the wall where plastic behaviour was expected. These include the ends and the middle of the bond beam and at the base and the mid-height of the wall.

The vertical floor deflections were measured using an automatic level with built-in plane-plate micrometer with 5 mm setting. It had an accuracy of $\pm 0.3 \mathrm{~mm}$ as used in the test set-up, established from repeatability checks.

\section{LOADING PROGRAMME}

Figure 5 illustrates the bi-directional loading programme adopted for testing. Generally, seismic testing is done cyclically but this test was largely monotonic as a result of delays caused by testing outside, which is very much more complex than laboratory testing, and the tight final completion date. The NZS4203:1992 [13] Serviceability Limit State Loads of $0.26 \mathrm{kPa}$, and Ultimate Limit State loads of $1.6 \mathrm{kPa}$ were calculated for Wellington and used as performance monitoring bench-marks. Note that $1.6 \mathrm{kPa}$ is equivalent to a self-weight seismic acceleration of $0.55 \mathrm{~g}$. This was obtained for an elastic response based on a fundamental period of $\mathrm{T}=0.65 \mathrm{~s}$ from $\mathrm{T}=0.09 \mathrm{H} . \mathrm{L}^{0.5}$ (Paulay and Priestley (1992) [15]), $C_{h}=0.68$ for intermediate soils, $\mathrm{S}_{\mathrm{p}}=0.67, \mathrm{R}=1.0$ for Category 4 structures and taking the wall mass as $290 \mathrm{~kg} / \mathrm{m}^{2}$ as listed in NZS4229:1986 [12].

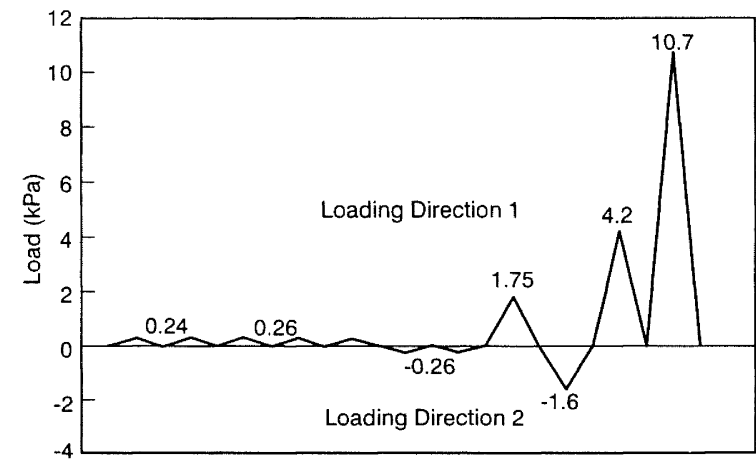

Figure 5: Loading programme.

\section{TEST RESULTS}

\section{Ribraft ${ }^{\mathrm{TM}}$ Floor}

The overall behaviour of the Ribraft ${ }^{\mathrm{TM}}$ floor was excellent. Some minor flexural cracks were found near the wall corners at $1.6 \mathrm{kPa}$ load applied from Loading Direction 1. These formed in a circular manner, measured approximately 0.2 $\mathrm{mm}$ in width and were possibly caused by the torsion and bending of the wall corner.

Some vertical uplift was measured at code load of $1.6 \mathrm{kPa}$ This results from the bending of both the wall and the floor associated with the eccentricity of the load resultant above the floor and the self-weight of the floor. The uplift amounted to $0.9 \mathrm{~mm}$ at the free end of the floor and $1.3 \mathrm{~mm}$ 
under the wall foundation for the two directions of load. A maximum strain of 100 microstrains was measured at this load. (yield strain $\varepsilon_{y}=2300$ microstrains). It is clear that the floor behaved extremely well at the ultimate code load.

Significant crushing in the cover concrete of the foundation beam under the main wall was also observed at $10.0 \mathrm{kPa}$. This was a result of the flexural compression internal actions at the base of the wall and the fact that the foundation concrete was weaker than the block concrete (see Tables 2 and 3). Strains in the floor reinforcement were less than 500 microstrains. The floor lifted by $2.2 \mathrm{~mm}$ at the free edge adjacent to the slab carrying the loading frame. The floor moved horizontally during the final loading stages to 1.80 $\mathrm{mm}$ at a load of $9.6 \mathrm{kPa}$.

\section{Masonry Wall}

The wall was constructed and then exposed to the weather for approximately seven weeks before testing. A strong El Nino weather pattern persisted throughout this time and the wall was subjected to strong, dry winds and many sunny days. Small cracks developed along the vertical mortar joints associated with the unfilled cells but these were considerably less than the widths permitted by the NZS3101:1995 for serviceability (NZS4230:1990 does not give explicit guidance on this aspect). The blocks were at least 60 days old and most shrinkage had therefore taken place and as an expansive admixture had been added to the grout, very little shrinkage could be expected to develop.

The graph of load versus bond-beam mid-span deflection of the main wall in Figure 6 illustrates the behaviour of the wall under the entire loading history. The stress in the wall reinforcement remained below the yield stress at load levels associated with both the Code Serviceability $(0.26 \mathrm{kPa})$ and Ultimate $(1.6 \mathrm{kPa})$ Limit States. The maximum deflection at mid-span of the bond-beam was $1.0 \mathrm{~mm}$ and $4.3 \mathrm{~mm}$, respectively. Many cracks were observed at both limit state loads. They were located in the horizontal and vertical mortar joints of the ungrouted cells and many of the vertical mortar joints in the bond beam. However, the maximum crack widths were all less than $0.2 \mathrm{~mm}$, the permissible value stated in Table 3.4, NZS3101 (1995) [16] for Serviceability Limit State.

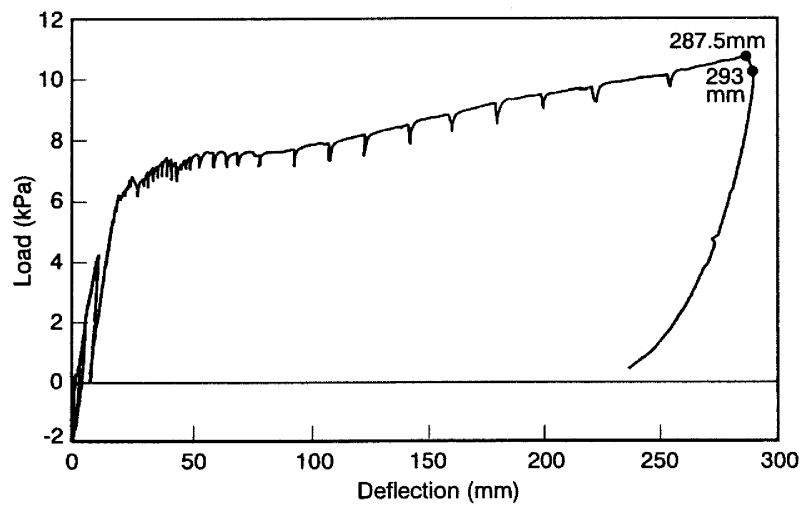

Figure 6: Load-deflection behaviour of main wall at midspan of the bond beam.
The bond beam deflections at the centre of the wall in Figure 5 are proportional to the applied pressure to approximately 6 $\mathrm{kPa}$. The stiffness of the wall decreased as inelastic deformation took place until at a central deflection of $90 \mathrm{~mm}$ the stiffness approached zero. Probably as a result of internal actions, the stiffness increased to a positive value of 15 $\mathrm{kPa} / \mathrm{m}$ and the response was linear until the test was stopped at $287 \mathrm{~mm}$. The authors surmise that this excellent performance may be a result of internal torsional actions and continuity of the bond beam into the return walls. The deflections along the bond beam for various loading pressures are shown in Figure 7. This shows a typically elastic behaviour to $6.0 \mathrm{kPa}$ with a continuous non-linear deflected shape. Plastic hinges started to form at $7.55 \mathrm{kPa}$ where discontinuities were recorded at the ends of the main wall and at $3.0 \mathrm{~m}$ and $6.0 \mathrm{~m}$ locations. This continued to a load of $8.0 \mathrm{kPa}$, after which some migration of the end hinges occurred to the $1.0 \mathrm{~m}$ and $8.0 \mathrm{~m}$ locations.
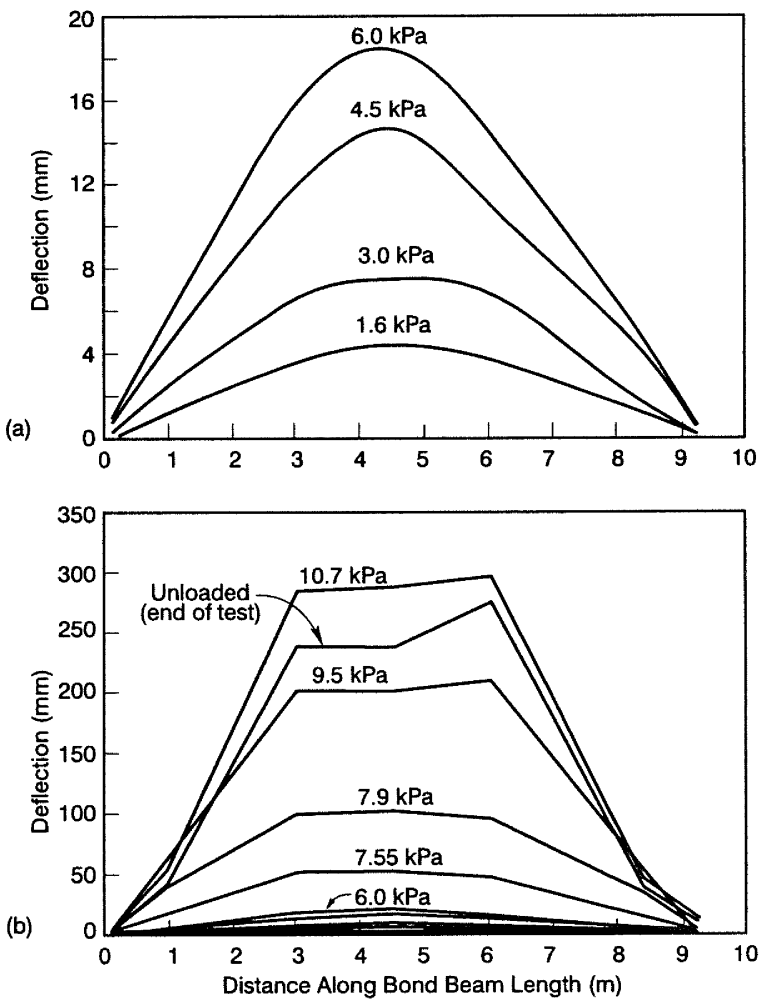

Figure 7: Bond beam deflections (horizontal plane) along the return walls versus load.

Curvatures along the top of the main wall and return walls were measured using a Demec gauge with an $880 \mathrm{~mm}$ gauge length. Figure 8 shows the variation of curvature along the walls clearly showing the formation of hinges at approximately $2.7 \mathrm{~m}$ and $7.7 \mathrm{~m}$ along the main wall and just inside the return walls. Figure 9 shows the vertical crack on the inside of Return Wall B approximately $400 \mathrm{~mm}$ from the inside corner. The crack penetrated through the wall and being narrower on the other side indicates that the wall was probably subjected to both flexure and uniform tension. The inclined crack and the base crack in the main wall are clearly shown in this photograph. The two return walls did not behave in a symmetrical fashion. This is shown in Figure 8 where the curvatures at the end of the main wall and Return 
Wall A are larger than those in Return Wall B. The lateral deflections associated with these curvatures are shown in Figure 10. Both walls are pulled in by the main wall as it shortens, but, whereas the free end of Wall A also moved in by $14 \mathrm{~mm}$, the free end of Wall B moved out by $5 \mathrm{~mm}$.
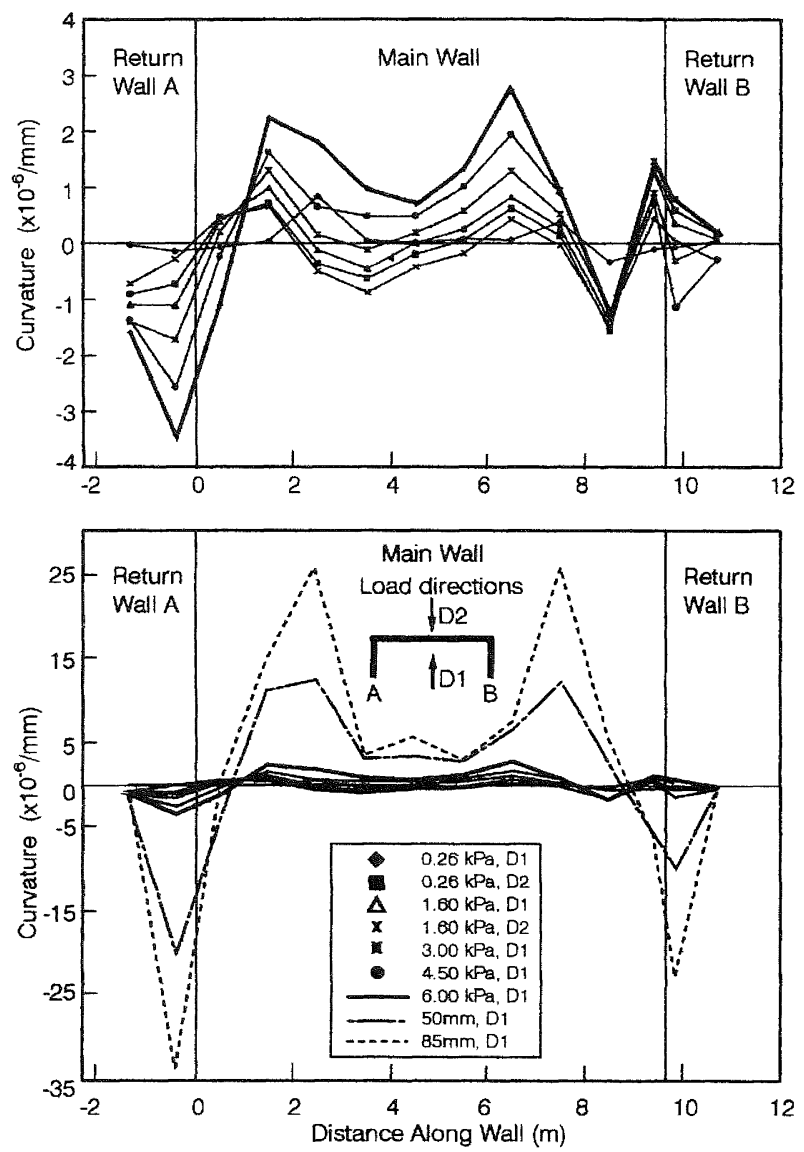

Figure 8: Bond beam curvatures along the top of the walls.

The deflection profiles of the main wall at the central section are shown in Figure 11. The deflected shape is nearly linear for all load pressures except for $-1.6 \mathrm{kPa}$. A possible reason for the $-1.6 \mathrm{kPa}$ plot lying on the "positive side" of the vertical axis is that under the preceding cycle of loading in the "positive" direction, there was a permanent deformation in the positive direction(associated with increased cracking), coupled with an apparent lower stiffness (out-of-plane in the positive direction compared to the negative direction). The opposite direction of loading at $-1.6 \mathrm{kPa}$ could not recover the entire amount of the deformation in the positive direction from the preceding cycle. Most of the rotation occurs in the mortar joint at the base of the wall and these were measured at locations $3.0 \mathrm{~m}$ from the ends of the main wall (see Figure 12). The rotation at $6.0 \mathrm{kPa}$ was approximately $0.0038 \mathrm{rad}$ and at about $7 \mathrm{kPa}$, the yield rotation of 0.0060 was developed. Using the bond beam deflection of $18.4 \mathrm{~mm}$ at a load of $6.0 \mathrm{kPa}$ in Figure 11, the base rotation is calculated to be $0.0077 \mathrm{rad}$. The theoretical yield rotation, based on an extreme fibre strain of 0.0025 and a steel yield strain of 0.0017 , is $0.0083 \mathrm{rad}$. This was associated with a bond beam deflection of $20.0 \mathrm{~mm}$ indicating that first yield may be taken as slightly more than $6.0 \mathrm{kPa}$.
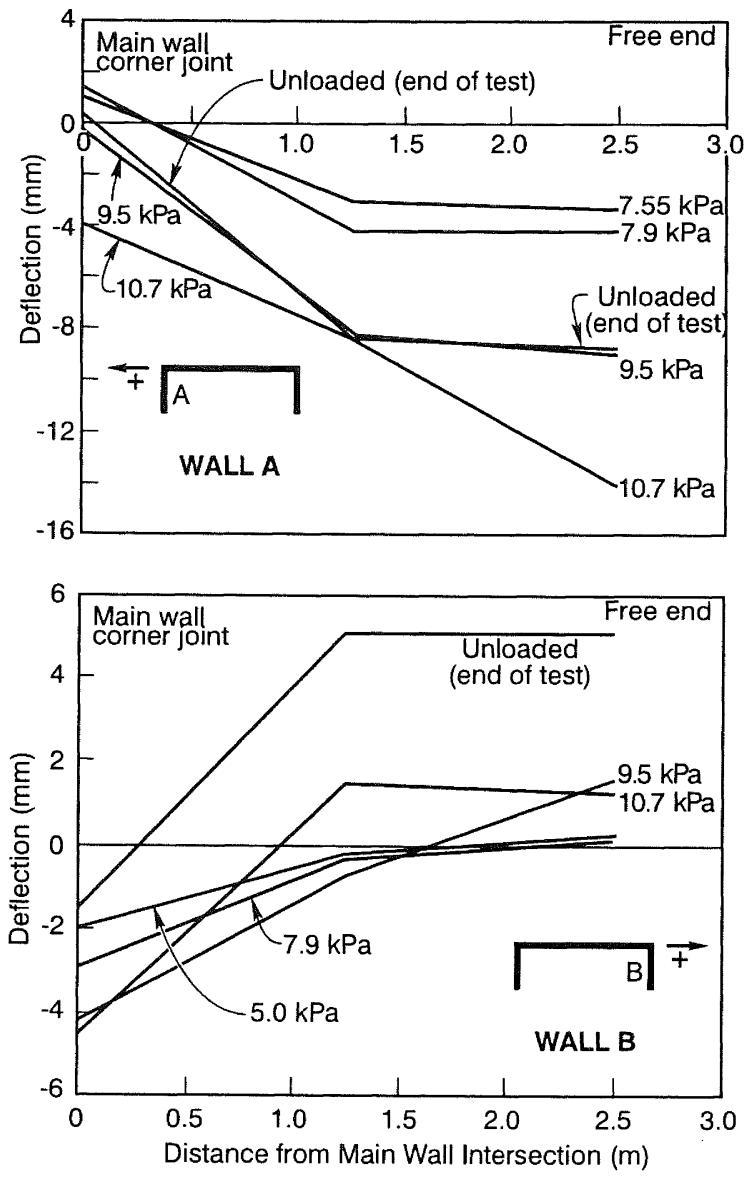

Figure 10: Bond beam deflections (horizontal plane) along the return walls versus load.

The theoretical bond beam yield curvature associated with the curvature of $0.0083 \mathrm{rad}$ is $41 \times 10^{-6} / \mathrm{mm}$. The measured curvatures in Figure 8 are average curvatures over $880 \mathrm{~mm}$ length and so do not give peak values, which generally occur across mortar joints. However, Figure 8 adequately indicates the approximate location of hinges as well as general distribution.

The measured strains in the reinforcement in the wall indicated that the steel remained elastic up to a face load of 6 $\mathrm{kPa}$. At a load of $7.6 \mathrm{kPa}$, the mid-span deflection had increased to $50 \mathrm{~mm}$ and yielding of reinforcement at a number of locations had occurred.

\section{YIELD LINE CALCULATIONS}

The strength capacity of the wall, calculated using Yield Line Theory (Park and Gamble, 1980 [8]), is defined by the formation of a yield line crack pattern and the development of the moment capacities along those lines. Yield Line Theory was used to calculate the capacity of the wall using 
the measured material properties and observed crack patterns. Figure 13 shows the distribution of yield lines representing the pattern of cracks in the main wall. The wall parts surrounded by the cracks are regarded as rigid plates and therefore not subjected to any bending deformations. The crack pattern on the face of the main wall is shown in the photograph in Figure 14.

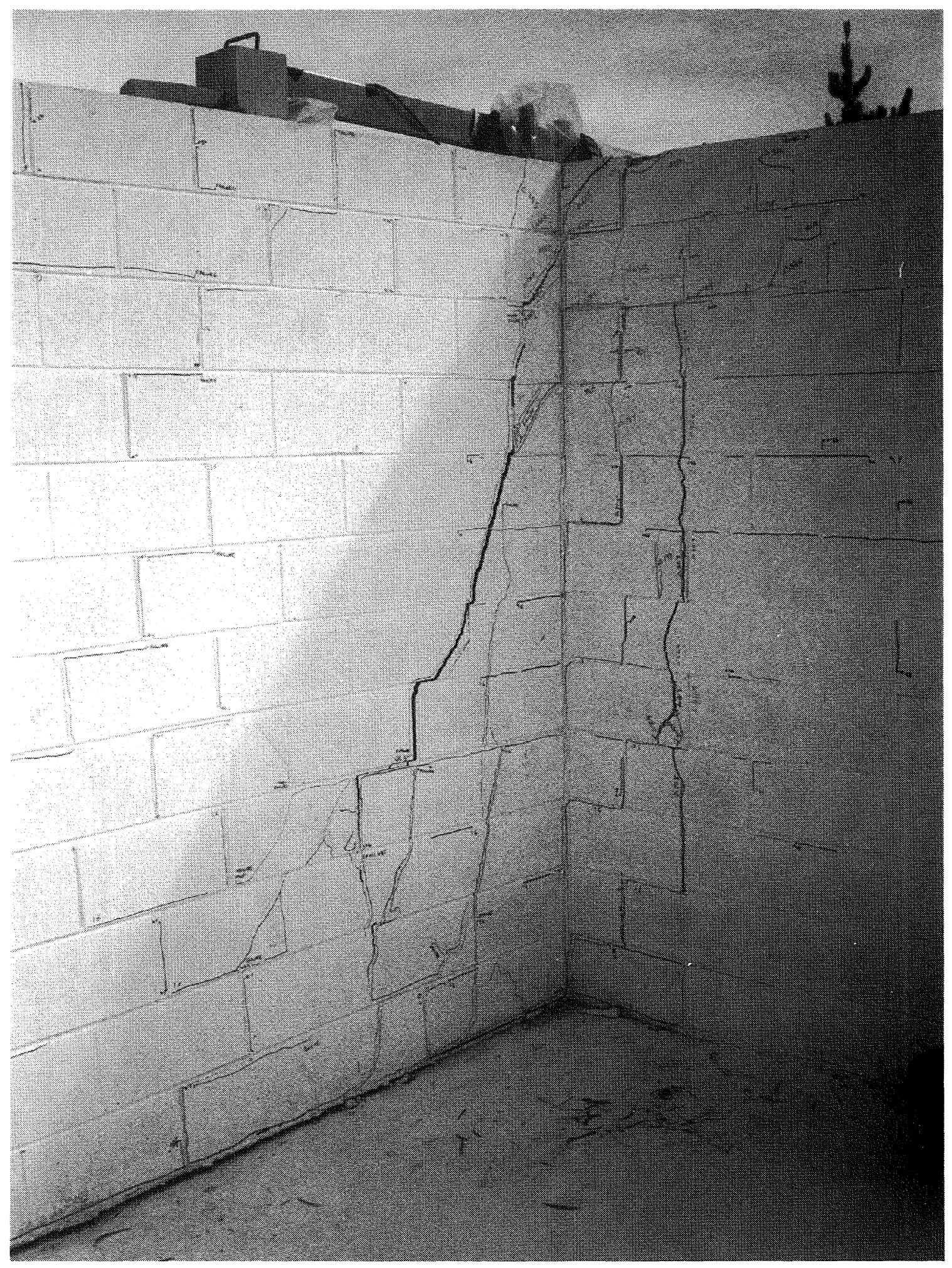

Figure 9: Main wall and return wall $B$ at the end of the test. 
(a)
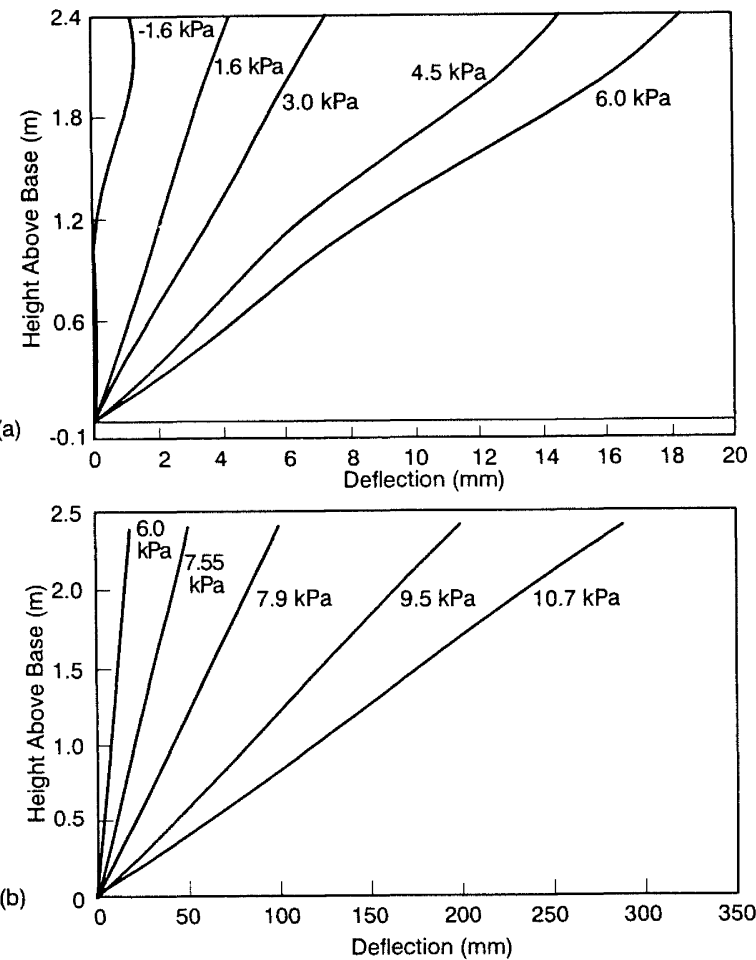

Figure 11: Deflection profiles at the middle of the main wall versus load.

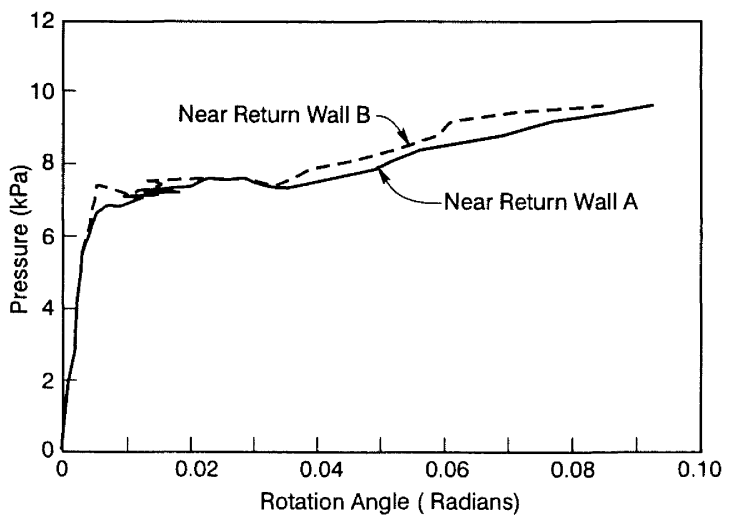

Figure 12: Rotation at the base of the main wall measured $3.0 \mathrm{~m}$ from each end.

Plastic hinge,

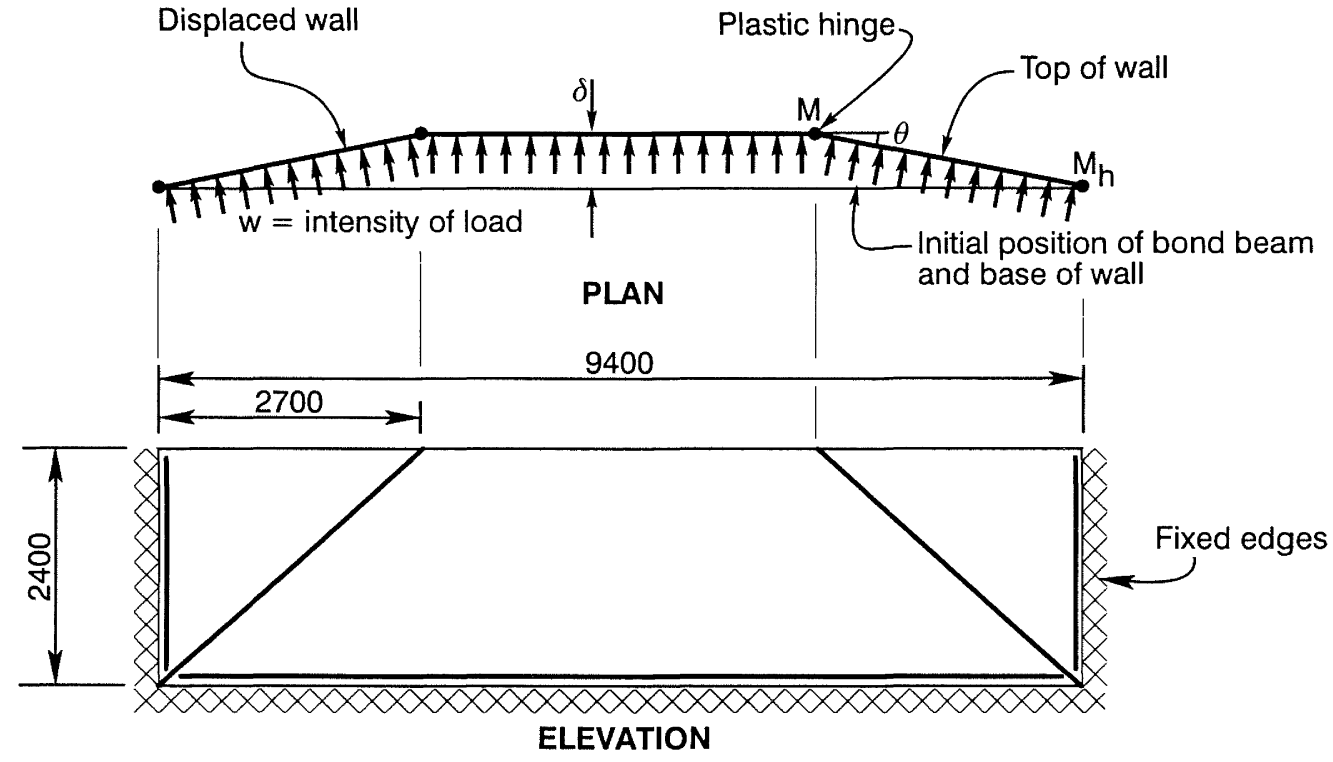

Figure 13: Vield line pattern for main wall. 
The external work done by the uniform load and the internal work done along the selected hinge lines in Figure 13 are

$$
\begin{aligned}
& \sum W \Delta=w * 0.5 * 2.4 * 2.7 * \frac{\delta}{3} * 2 * 2 \\
& +{ }^{2} *(9.4-2 * 2.7) * 2.4 * \frac{\delta}{2} \\
& =9.12 * w * \delta
\end{aligned}
$$

$$
\begin{aligned}
& \sum M \theta \ell=M_{h} * \frac{\delta}{2.7} * 2.4 * 2 * 2 \\
& +M_{{ }_{v}} * \frac{\delta}{2.4} * 2.4 * 2+M_{v} * \frac{\delta}{2.4} * 9.4 \\
& =3.55 M_{h} \delta+5.92 M_{v} \delta
\end{aligned}
$$

where:

$$
\begin{aligned}
& \delta=\text { an out-of-plane displacement at the top of } \\
& \mathrm{w}=\text { ultimate uniform applied face load }(\mathrm{kPa}) \\
& \mathrm{M}_{\mathrm{v}}=\text { ultimate moment capacity of vertically } \\
& \mathrm{M}_{\mathrm{h}}=\text { ultimate moment capacity of horizontally } \\
& \mathrm{W}=\text { resultant applied load }(\mathrm{kN}) \\
& \Delta=\text { deflection associated with the resultant load } \\
& \text { (m) } \\
& \mathrm{M}=\text { bending moment }(\mathrm{kNm}) \\
& \theta=\text { angular rotation }(\mathrm{rad}) \\
& \ell=\text { length of yield line }(\mathrm{m})
\end{aligned}
$$

The moment capacities $\mathrm{M}$ are calculated from

$$
M=A_{s} f_{y}\left(d-\frac{0.59 A_{s} f_{y}}{f_{m}^{\prime} b}\right)
$$

Where $A_{s}=$ area of steel; $f_{y}=$ yield stress of the steel; $d=$ distance between steel and the compression face of the section; $\mathrm{f}_{\mathrm{m}}=$ masonry strength and $\mathrm{b}=$ width of section. The moment capacity is insensitive to masonry strength because the wall is lightly (under) reinforced.

The moment capacity of the bond-beam, based on $f_{m}=19.5$ $\mathrm{MPa}$, was calculated to be equal to $11.09 \mathrm{kNm}$. This was used for the left and right-hand boundaries shown in Figure 13. The joint between the main wall and the return walls was fixed because of the continuity which developed during the wall test. The moment capacity of 12 bars along the base of the wall was $41.2 \mathrm{kNm}$

Equating Eq. 2 and 3, a maximum load of $\mathrm{w}=5.0 \mathrm{kPa}$ was calculated. This load slightly underestimated the onset of plasticity in the wall at a load of approximately $6 \mathrm{kPa}$.

\section{IMPLICATIONS FOR FUTURE CODES}

The implications of the behaviour of the wall on domestic structures are many. At the Ultimate Limit State code level load of $1.6 \mathrm{kPa}$, the cracks were well distributed, the widths less than $0.2 \mathrm{~mm}$ and the maximum deflection of the bond beam was only $4.3 \mathrm{~mm}$. Yield line theory calculations resulted in an ultimate load of $5.0 \mathrm{kPa}$, a conservative estimate. The experiment showed that the wall was capable of sustaining loads of up to $6 \mathrm{kPa}$ with only minor and repairable damage. At this stage, the bond beam of the wall had deflected $18 \mathrm{~mm}$ at the middle, and this could possibly be nearing the limits of allowable movement at the Ultimate Limit State of nailed and bolted connections joining the floor joists and rafters to the wall.

The Ultimate Limit State criterion in NZS4203: 1992 [13] for maximum permissible deflection is $50 \mathrm{~mm}$ in the bond-beam ( $2 \%$ of the height of the storey). This deflection is associated with a ductility of 2.5 based on the first yield deflection of $20.0 \mathrm{~mm}$. The $50 \mathrm{~mm}$ deflection was achieved at a load of $7.6 \mathrm{kPa}, 4.8$ times the Ultimate State Code Load of $1.6 \mathrm{kPa}$. The inclusion of some degree of diaphragm action as typically available from floors and roof members in structures could possibly see even higher loads being sustained.

The test results proved that the wall was capable of undergoing large amounts of inelastic deformation without collapse. In this respect, designing such walls elastically, as done for performance verification purposes in this project, may appear to be over-conservative.

\section{CONCLUSIONS \& OBSERVATIONS}

\section{Ribraft $^{\text {TM }}$ Floor}

1. The behaviour of the floor was excellent under the code level Ultimate Limit State loading of $1.6 \mathrm{kPa}$ sustaining only minor flexural cracking.

2. The return wall foundations sustained severe diagonal cracks at the slab corners, at the maximum load of $10.7 \mathrm{kPa}$. These were a continuation of the major diagonal cracks sustained by the main wall.

3. The main wall foundation region started crushing at a load of approximately $7.9 \mathrm{kPa}$. Crushing occurred because the compressive strength of the block wall was greater than that of the floor and due to the foundation detail used, in which the wall and foundation faces coincided

4. The floor underwent minor uplift and horizontal sliding during the testing programme and did not permanently damage the floor. However, it should be noted that the effects discussed in points 3 and 4 occurred at loads considerably greater than the code ultimate load.

5. At the completion of testing, the floor was in a repairable state. Strains in the reinforcement remained elastic throughout the testing programme. 


\section{Masonry wall}

The overall excellent performance of the wall leads to the conclusion that the existing criteria as set out in NZS4229: 1986 [12] is conservative (based on elastic design of such walls.) The test results have shown that such walls can effectively carry code level loading using bond-beam details generally used only for walls with horizontal diaphragm support. They have also shown that bond-beam reinforcement levels may be decreased below that currently stipulated in Table 8.1, NZS4229: 1986 [12], and that the lengths of walls between returns may be increased above levels currently permitted.

1. Walls with no penetrations, up to $9 \mathrm{~m}$ long, may be built without control joints, provided that the blocks have matured and that the grout has been suitably placed and compacted. Shrinkage cracks between the mortar and blocks were numerous, yet very small. No large shrinkage cracks had appeared in 3 months. It is recommended that expansive admixtures are used for this type of construction and in combination with concrete blocks which have matured sufficiently that most of the shrinkage has taken place before laying.

2. The diagonal bars installed in the bond-beam corner joints, for the enhancement of shear capacity, performed well. This detail is recommended for use in bond-beam corner joints of walls.

3. The wall behaved elastically up to a load of $6 \mathrm{kPa}$. At this load, the maximum deflection at the top of the wall was $18 \mathrm{~mm}$, which may lead to the onset of failure in some forms of nailed connections between floor joists or rafters and a wall.

4. Yield line theory can be used to predict the ultimate load, provided that the bond beam strength is included in the calculation. This infers full fixity along the ends of the wall adjacent to the returns, as well as base fixity. This method resulted in an ultimate face load of $5.0 \mathrm{kPa}$. This underestimated the load at first yield, which occurred along the base of the wall, by approximately $17 \%$ and the effective ultimate load based on $2 \%$ drift by $34 \%$.

5. Wall performance at both Code level Serviceability $(0.26 \mathrm{kPa})$ and Ultimate $(1.6 \mathrm{kPa})$ Limit State loads, based on self weight only, was elastic. Cracking observed at both Serviceability and Ultimate Limit State code loads was confined to mortar joints, and crack widths measured were less than the NZS3 101:1995 [16] criterion of $0.2 \mathrm{~mm}$ for in-service performance.

6. The deflection limit in NZS4203: 1992 [13] for Ultimate Limit State behaviour of $2.4 \mathrm{~m}$ high walls, was $50 \mathrm{~mm}$ ( $2 \%$ of the storey height). This was reached at a load of $7.6 \mathrm{kPa}$, when the wall had reached a displacement ductility (based on mid-span bond beam deflection) of approximately 2.5 .

7. The wall did not collapse: the test was ended when the wall appeared to be supported by the return walls through the bond beam and by possible internal actions within the wall. It was capable of sustaining increased loading at the final test load of $10.7 \mathrm{kPa}$ and a deflection of $288 \mathrm{~mm}$ at the mid-span of the bondbeam. The calculated in-plane capacity of the return walls, based on the tensile yield stress of the bars in the bond beams of the return walls, showed that they can provide restraint to the main wall to a load of 12 $\mathrm{kPa}$.

8. The wall behaved in a ductile manner, reaching a displacement ductility of at least 15 (based on the mid-span deflection of the top of the bond beam.)

9. The likely seismic demand on this type of wall in the out-of-plane direction, will be considerably less than the capacity of the wall.

\section{ACKNOWLEDGEMENTS}

The authors wish to acknowledge the financial support of Firth Industries Limited. Special thanks are due to the Department of Civil Engineering, University of Canterbury, for the technical support and to Mr. Russel McConchie for his support and expertise.

\section{REFERENCES}

1. Singh, S. (1998), "The Performance of a Partially Grouted Reinforced Concrete Masonry Wall and Ribraft ${ }^{\mathrm{TM}}$ Floor under Simulated Seismic Loading", M.E. Report, Dept. of Civil Engineering, University of Canterbury, February.

2. Adham et al. (1990), "Out-of-plane Dynamic Testing of Concrete Masonry Walls", Fifth North American Masonry Conference, Urbana-Champaign, pp 385396.

3. Abboud B.E. and Hamid A.. A., (1990), "Behaviour of Model Concrete Masonry Slender Walls under Out-of-plane Lateral Loads", Fifth North American Masonry Conference, Urbana-Champaign, pp 441454.

4. Sveinsson, B.I., Kelly, T.E., Mayes, R.L. and Jones, L.R. (1988), "Out Of Plane Response of Masonry Walls to Seismic Loads", Fourth North American Masonry Conference, Los Angeles, California, Paper 46 , pp $46.1-46.10$.

5. Hamid, A. A. et al. (1990), "Hysteretic Response and Ductility of Reinforced Concrete Masonry Walls under Out-of-plane Loading", Fifth North American Masonry Conference, Urbana-Champaign, pp $397-$ 409.

6. Abboud, B.E., Hamid, A. A. and Harris, H. G (1996), "Flexural Behaviour of Reinforced Concrete Masonry Walls under Out-of-plane Monotonic Loads", ACI Structural Journal , Vol. 93, May-June, pp 327-335. 
7. Priestley, M. J. N. et al. (1994), "The US-TCCMAR Full-scale Five-storey Masonry Research Building Test", University of California, San Diego.

8. Park, R. and Gamble, W.L. (1980), "Reinforced Concrete Slabs", John Wiley and Sons, New York, pp 274-464.

9. Essawy, A. S. and Drysdale, R. G. (1988), "Evaluation of Available Design Methods For Masonry Walls Subjected To Out-Of-Plane Loading", Fourth North American Masonry Conference, LA, California, Paper 32, pp 32-1 - 32-12.

10. Seah, C.K., Dawe, J.L. and Dukuze, A. (1993), “A Yield line Analysis of Concrete Masonry Panels for use on Microcomputers", Sixth North American Masonry Conference, Pennsylvania.

11. Abboud, B.E., Lu Xin and Schmitt, F.C. (1993), "An Evaluation of Three Current Deflection Methods for Predicting the Lateral Deflection of Masonry Walls", Sixth North American Masonry Conference, Pennsylvania, pp 73-86.
12. NZS4229: 1986: "Code of Practice for Masonry Structures Not Requiring Specific Design", Standards Association of New Zealand.

13. NZS4203: 1992: "Code of Practice for General Structural Design and Design Loadings for Buildings", Standards New Zealand.

14. NZS4230: 1990: "Code of Practice for the Design of Masonry Structures", Standards Association of New Zealand.

15. Paulay, T. and Priestley, M. J. N. (1992), "Seismic Design of Reinforced Concrete and Masonry Buildings", John Wiley and Sons Inc., pp 532-636.

16. NZS3 101: 1995: "Concrete Structures Standard", Standards New Zealand.

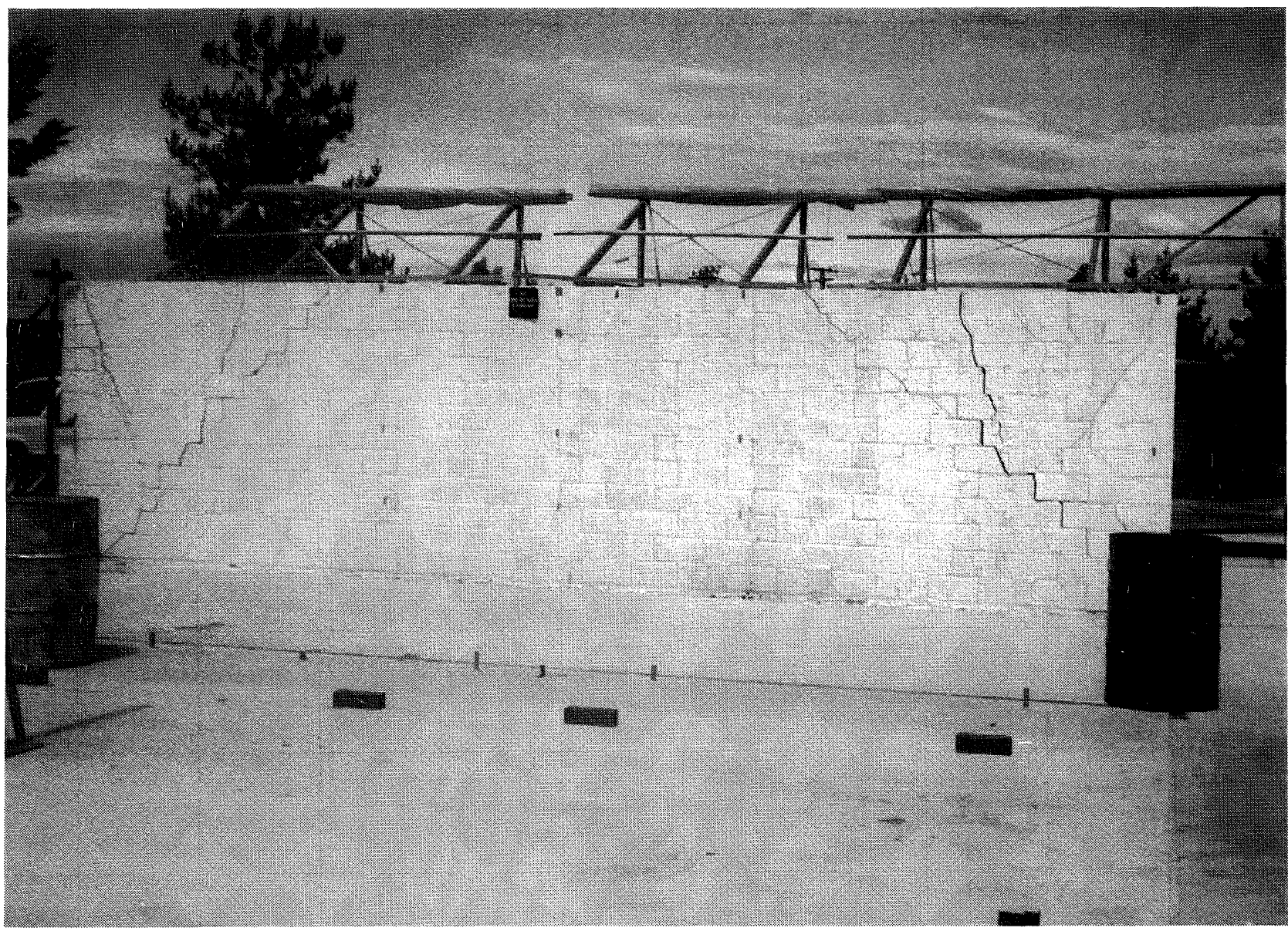

Figure 14: Elevation of wall at the end of the test. 